\title{
Analisis Volatilitas Indeks Harga Saham Gabungan dan Individual dengan Exponential Moving Average dalam Menghitung Risiko Saham Melalui Estimasi Beta \\ (Kasus Saham Perbankan di Bursa Efek Indonesia)
}

\author{
I Komang Gede Widiarta ${ }^{1}$
}

\begin{abstract}
Abstrak
Investasi di bursa saham sejak tahun 1998 masih kalah dibandingkan dengan investasi yang lain, karena investor berpendapat bahwa investasi tersebut memiliki tingkat risiko yang tidak dapat diprediksi.

Tujuan dari penelitian ini adalah, untuk mengetahui tingkat risiko saham (kasus saham perbankan) di Bursa Efek Indonesia melalui perhitungan estimasi beta dan metode Exponential Moving Average, dan juga untuk mengetahui conditional volatility yang menjelaskan seluruh perbedaan cross-sectional di dalam pengembalian return saham melalui risiko differential saham.

Model penelitian ini didasarkan pada model pasar (market model), yaitu return historis saham diregresi dengan return historis suatu proksi portofolio pasar. Return pasar yang digunakan sebagai proksi dalam penelitian ini adalah return dari Indeks Harga Saham Gabungan (IHSG). Sedangkan metode penelitian yang digunakan dalam penelitian ini adalah studi deskriptif yang bertujuan untuk mengetahui dan mampu menjelaskan karakteristik variable yang diteliti dalam suatu situasi. Observasi dilakukan pada 27 bank dari total 34 bank yang terdaftar sebagai emiten di Bursa Efek Indonesia. Enam dari bank tersebut masih dalam proses IPO dan satu bank belum melakukan transaksi yaitu Bank Jabar dan Banten. Periode pengamatan yang dipakai adalah dari bulan Januari 2008 hingga bulan Desember 2010.

Hasil penelitian ini menunjukan bahwa tingkat risiko saham perbankan di Bursa Efek Indonesia dapat dihitung melalui estimasi beta dan metode rata-rata bergerak Exponential Moving Average dengan hasil uji bias yang menunjukan nilai 0,97 dan tingkat kesalahan estimasi beta melalui metode mean absolute percent error (MAPE) sebesar 5,73\%. Conditional volatility dapat menjelaskan seluruh perbedaan crosssectional di dalam pengembalian return saham melalui risiko differential saham perbankan di Bursa Efek Indonesia
\end{abstract}

Kata Kunci : Analisis Volatilitas, Estimasi Beta, Exponential Moving Avarage, Menghitung Resiko Saham

\section{Pendahuluan}

Investasi di bursa saham sejak tahun 1998 masih kalah dibandingkan dengan investasi-investasi yang lain, karena investor berpendapat bahwa investasi tersebut memiliki tingkat risiko yang tidak dapat diprediksi.

Ronald Osak $(2000 ; 1)$ mengutip pernyataan Sukarman (1999) yang menyebutkan pada tahun 1998, investasi dalam negeri didominasi deposito berjangka sebesar 45\%, sedangkan kecenderungan berinvestasi secara rinci terlihat dari hasil pantauan majalah infobank tahun 1998. Dari 500 responden yang masuk didapatkan hasil sebagai berikut:
Tabel 1

Tingkat Investasi Tahun 1998 di Indonesia

\begin{tabular}{|c|l|r|}
\hline No & \multicolumn{1}{|c|}{ Investasi } & Tingkat Investasi \\
\hline 1 & Deposito & $43,8 \%$ \\
\hline 2 & Tanah & $14,8 \%$ \\
\hline 3 & Rumah & $10,7 \%$ \\
\hline 4 & Valas & $9,5 \%$ \\
\hline 5 & Emas & $8,4 \%$ \\
\hline 6 & Membuka usaha & $6 \%$ \\
\hline 7 & Saham & $5,2 \%$ \\
\hline 8 & Obligasi & $1,8 \%$ \\
\hline
\end{tabular}

Sumber : Majalah Infobank tahun 1998

Anggapan bahwa pergerakan harga saham pada saat ini tidak dapat diprediksi atau diramalkan (Totally 
Random) dan hanya mengikuti pergerakan trend tidak sepenuhnya benar. Jika anggapan tersebut menjadi landasan berfikir dan dijadikan alat pengambil keputusan para investor maka investor tidak akan mengetahui timing yang tepat untuk melakukan pembelian ataupun penjualan, bahkan kerap terjadi aksi panic selling yang mengakibatkan penurunan harga yang relatif cepat.

Sebagai gambaran sikap investor yang hanya mengikuti pergerakan indeks harga saham gabungan di bursa tanpa melakukan prediksi akan menimbulkan false signal, seperti yang diungkapkan oleh Adler Haymans Manurung (2008;1), dimana IHSG pada level 392.036 dan meningkat sampai pada akhir tahun 2007 ke level 2750. Semua pihak merasa senang karena terjadi kenaikan yang berlipat ganda selama 6 tahun terakhir. Bahkan analyst sepakat dan selalu menyatakan bahwa IHSG akan ditutup pada level 3200 pada akhir tahun 2008. Banyak pihak yang mengambil kesempatan bahwa kenaikan bursa merupakan kerja kerasnya dan harus mendapat imbalan atas kenaikan bursa tersebut.

Keberpihakan bursa untuk pihak-pihak tersebut rupanya tidak seterusnya karena lambat laun bursa mengalami keterpurukan. Situasi Amerika yang semakin buruk dikarenakan banyak lembaga yang mengalami kerugian bahkan melakukan pernyataan bangkrut seperti Lehman Brothers turut membuat Bursa Efek Indonesia mengalami drop yang cukup tajam. Pada pertengahan September 2008 IHSG mencapai level 1600 dan merupakan drop paling tajam dalam sejarah bursa efek Indonesia.

Terdapat beberapa penelitian ilmiah yang meneliti masalah risiko apa yang harus diperhatikan dalam berinvestasi saham, untuk meminimalisir kerugian yang diakibatkan oleh beberapa faktor yang sering terjadi di bursa saham, seperti adanya Assymetric Information, False Signal, Liquidasi saham, dan perbedaan cara mengetahui conditional volatility untuk menjelaskan seluruh perbedaan cross-sectional di dalam pengembalian return saham melalui risiko differential (Fama dan French 1996) yang dikutip Anton (2006;2).

Anton (2006) melakukan penelitian untuk menguji secara empiris adanya fenomena time varying volatility terjadi dalam fluktuasi return saham dan volatilitas, menguji adanya asymmetric effect dalam return saham dan volatilitas, serta untuk mengestimasi secara empiris bahwa volume perdagangan berpengaruh pada return saham dan volatilitas return saham.

Data yang digunakan dalam penelitian ini adalah indeks harga saham penutupan harian (closing price) dan jumlah saham yang diperdagangkan dari indeks harga saham LQ 45 periode 2003-2004. Untuk kepentingan itu dikembangkan basis model estimasi yaitu model GARCH dan model EGARCH.

Hasil penelitian menunjukkan bahwa return saham di Indonesia memiliki permasalahan time varying volatility, tetapi tidak terjadi leverage effect pada volatilitas return saham, serta return saham tidak dipengaruhi oleh volume perdagangan. Ternyata pasar modal Indonesia termasuk pasar bentuk lemah. Pasar dikatakan dalam bentuk lemah jika harga mencerminkan informasi masa lampau. Implikasi dari efisiensi bentuk lemah adalah investor tidak akan memperoleh keuntungan abnormal yang konsisten dengan menggunakan informasi di masa lampau. Hal ini menggambarkan bahwa informasi masa lampau tidak bisa dipakai untuk memprediksi harga di masa mendatang.

I Wayan Ramantha (2006) melakukan penelitian untuk mengukur tingkat likuiditas saham melalui variabel bid-ask spread dan menyimpulkan, bahwa dalam volume perdagangan saham berpengaruh negatif signifikan terhadap bid-ask spread, demikian juga dengan volatilitas harga saham yang berpengaruh negatif signifikan terhadap bid-ask spread. Pengaruh negatif signifikan dari variabel dalam volume perdagangan saham dan volatilitas harga saham terhadap bid-ask spread, berarti semakin tertariknya investor untuk berinvestasi pada saham tersebut, karena mampu meningkatkan likuiditas sahamnya.

Kumianny A. Saputra, Elly dan Pwee Leng (1999) telah terlebih dahulu meneliti variabel-variabel tersebut di atas yaitu meneliti pengaruh risiko sistimatis dan likuidasi saham yang diukur dengan besarnya bid-ask spread terhadap tingkat pengembalian saham dari badan-badan usaha yang go public di PT. BEJ, dan untuk mengetahui berapa besar proporsi masing-masing variabel dalam mempengaruhi tingkat pengembalian saham.

Hasil akhir dari penelitian tersebut menunjukan bahwa baik risiko sistematis maupun likuiditas saham yang diukur dengan besarnya bid-ask spread mempunyai pengaruh yang signifikan terhadap tingkat pengembalian saham dari badan-badan usaha yang go public di Indonesia. Dari uji hipotesis didapatkan hasil bahwa risiko 
sistematis lebih mempengaruhi tingkat pengembalian suatu saham dibandingkan dengan likuiditas saham yang diukur dengan besarnya bid-ask spread.

Penelitian ini berfokus pada analisis teknikal yang berdasarkan konsep bahwa faktor apa pun yang telah dijadikan pertimbangan oleh para pelaku di bursa (saham mau pun komoditi) untuk mengambil keputusan jual-beli, secara kolektif berpengaruh pada tingkat harga yang mencerminkan hasil interaksi antara permintaan dan penawaran secara total. Semua faktor tersebut yang dikenal sebagai unsur-unsur fundamental dengan demikian telah masuk sebelumnya ke dalam bursa dan direfleksikan dalam gerak harga dan volume yang belakangan terjadi di sana. Pasar modal di Indonesia merupakan pasar modal bentuk lemah seperti yang di sebutkan oleh penelitian sebelumnya oleh Anton (2006), berimplikasi berkurangnya investor dalam mendapatkan abnormal return. Dalam penelitian ini dianalisis suatu cara untuk meminimalisir halhal tersebut di atas, dengan mengetahui waktu yang tepat untuk berinvestasi dan pemilihan investasi mana saja yang menguntungkan melalui analisis volatilitas harga dan tingkat risiko sistematis di bursa saham.

Penelitian tersebut ditujukan pula untuk melengkapi penelitian yang telah dilakukan sebelumnya, tentang hubungan volatilitas saham dan risiko sitematis yang keberadaannya tidak bisa dieliminasi oleh diversifikasi investasi. Dengan meneliti suatu cara untuk mengetahui conditional volatility untuk menjelaskan seluruh perbedaan cross-sectional di dalam pengembalian return saham melalui risiko differential. Tahap pertama, untuk mengetahui pergerakan volatilitas saham penelitian ini menggunakan metode yang familiar digunakan di bursa saham, yaitu metode XMA (Exponential Moving average) yaitu metode rata-rata bergerak yang telah mengalami penyempurnaan dari metode rata-rata bergerak sebelumnya dengan penambahan bobot nilai penghalusan dalam mendapatkan nilai volatilitas harga yang akurat. Tahap kedua adalah tahap pengukuran risiko sistematis melalui metode indeks tunggal dari wiliam sharp yang merupakan penyederhanaan metode pengukuran pricing model dari Markowitz dengan menitik beratkan pada dua komponen, yaitu risiko pasar dan risiko keunikan perusahaan. Sedangkan pengukuran model Markowitz menghitung kovarians melalui penggunaan matriks hubungan varian-kovarians, yang memerlukan perhitungan yang kompleks.

Pelaku di bursa saham yang pada dasarnya terdiri dari dua kelompok, yaitu investor yang memiliki pandangan jangka panjang dan investor yang memiliki pandangan jangka pendek, keduanya tidak ada yang bisa luput dari pengaruh teknikal yang sedang berlaku di sana. Yang disebut lebih dahulu adalah mereka yang berpatokan jangka panjang karena berharap untuk mendapatkan penghasilan dari dua sumber pendapatan, yaitu dividen dan kenaikan harga saham. Karena dividen hanya dikeluarkan paling cepat setengah tahun sekali, maka investor harus menahan sahamnya selama paling sedikit enam bulan juga. Kenaikan harga saham sepantasnya disebabkan perbaikan kinerja emitennya, namun bisa juga disebabkan faktor lain seperti penurunan suku bunga bank, suasana politik dan keamanan yang bertambah tenang dan baik, dsb. Maka investor akan lebih berhaluan fundamental sehingga mempunyai pekerjaan rumah yang lebih banyak daripada hanya memperhatikan perkembangan harga dan volume.

Kelompok investor yang memiliki pandangan jangka pendek terutama mengharapkan penghasilan dari kenaikan harga saham, namun bila ada penyelenggaraan short-selling (menjual barang yang tidak dimiliki untuk dibeli dalam batas waktu yang telah ditetapkan), penurunan harga bisa juga menghasillkan keuntungan. Karena Investor yang memiliki pandangan jangka pendek tidak berniat untuk memegang saham lama-lama seperti investor yang berpatokan jangka panjang, yang diperhatikannya adalah grafik harga dan volume saja. Meskipun berkesan sederhana, yaitu seolah-olah hanya mengikuti perkembangan dua besaran saja, namun masih ada tiga sub-komponen harga yang lain, yaitu pembukaan, tertinggi, dan terrendah. Kemudian pola pergerakannya masih terbagi dalam dua kategori, yaitu analisis tradisional yang mencakup 19 pola dasar baku serta penggunaan garis lurus, dan analisis dengan komputer. Yang disebut belakangan mencakup enam kelompok, yaitu arah gejala (trend), volatilitas, momentum, siklus, kekuatan pasar serta indikator pendukung dan penghambat, sehingga paling sedikit telah tercipta 92 cara pembacaan atau pelacakan corak grafik, seperti MACD (Moving Average Convergence Divergence), RSI (Relative Strength Index), Stochastic Oscillator, Williams R, Chaikin Money Flow, Aroon Index, 
Bolinger Bands, dan sebagainya. Adalah pengalaman pakar analisis teknikal yang akan menentukan perangkat indikator manakah yang dianggap cocok dalam situasi tertentu. Maka analisis teknikal tidak kalah rumitnya dari analisis fundamental.
Untuk membaca pola pergerakan tersebut maka digunakanlah beberapa metode dasar yang mendasari metode analisa yang lain dalam membaca pergerakan saham ini, yaitu metode rata-rata bergerak (Moving average). Penerapan metode tersebut dapat dilihat dari contoh Gambar 1 di bawah ini:

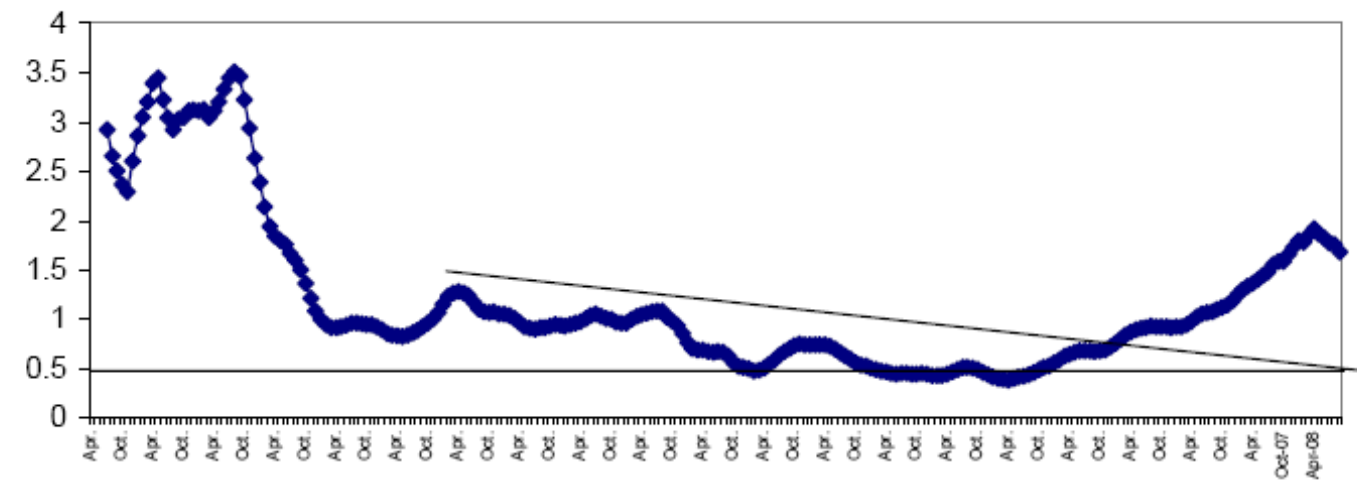

\section{Gambar 1}

\section{Siklus Bursa Saham (MA 6 Bulan)}

Sumber : PT. Bursa Efek Jakarta tahun 1988

Metode dasar ini sangat sederhana tetapi memiliki peranan penting karena bisa diaplikasikan terhadap pergerakan harga atau volume dan metode ini juga dapat digunakan untuk menstabilkan metode analisa lainnya untuk menghilangkan false signal dari metode yang lainnya, seperti menstabilkan garis RSI, Stockhastik, Wiliams R. dan lainnya.

Dalam perkembangnya metode rata-rata bergerak ini mengalami penyempurnaan untuk menambah tingkat akurasinya. Dari metode rata-rata bergerak sederhana (Simple Moving average), kemudian berkembang menjadi WMA (Weighted Moving average), sampai dengan XMA (Exponential Moving average).

Menurut Hendra Syamsir (2004;135), bahwa:

"anggapan yang menyatakan tidak terdapat perbedaan antara SMA, WMA dan XMA, karena adanya aturan pembacaan grafik yang sama adalah tidaklah benar, disebabkan ketiga metode rata-rata tersebut memiliki sensititivitas serta kepekaan yang berbeda".

Perbedaan tersebut akibat adanya sistem pembobotan dan koefisien penghalusan.

Harga yang dihasillkan oleh metode peramalan tersebut juga dapat digunakan untuk melihat berapa besar risiko dari return individual saham terhadap return indeks saham gabungan (IHSG) yang sering digunakan sebagai proxy return pasar melalui estimasi beta.

Risiko sistematis atau risiko yang tidak dapat didiversifikasi (dihindarkan), disebut juga dengan risiko pasar. Risiko ini berkaitan dengan kondisi yang terjadi di pasar secara umum, misalnya perubahan dalam perekonomian secara makro, risiko tingkat bunga, risiko politik, risiko inflasi, risiko nilai tukar dan risiko pasar. Risiko ini mempengaruhi semua perusahaan dan karenanya tidak bisa dihilangkan dengan diversifikasi. Parameter yang digunakan dalam mengukur risiko ini adalah beta.

Michell suharli $(2005 ; 104)$ mengutip pendapat Jones (2000;178), yang menjelaskan bahwa, "Beta a measure of valatility, or relative systematic risk". Dimana pengertian volatilitas di sini adalah sebagai fluktuasi dari return suatu sekuritas dalam suatu periode tertentu. Jika fluktuasi return sekuritas secara statistik mengikuti fluktuasi return pasar, maka beta dari sekuritas tersebut bernilai 1. Misalnya apabila return pasar naik sebesar 5\%, maka investor akan menghargapkan kenaikan return sekuritasnya sebesar 5\% pula.

Dengan menggunakan metode rata-rata bergerak dan metode estimasi beta berguna untuk mengetahui dengan cepat berapa besar risiko relatif suatu investasi berupa saham dalam periode investasi tertentu, merupakan 
hal yang diharapkan dapat membantu membuat gambaran secara cepat dalam membuat keputusan investasi di bursa saham.

Dalam hal ini beta dapat diestimasi setelah mengetahui return dari tingkat naik turunnya harga saham (volatilitas saham).

Seperti yang telah disebutkan di atas Istilah volatilitas digunakan sebagai ukuran responsiveness perolehan oleh suatu sekuritas atau portofolio terhadap perubahan-perubahan perolehan di pasar saham sebagai keseluruhan, seperti yang dikemukakan oleh Sharpe (1971) dikutip oleh Anton (2006:1).

Dengan berlandaskan uraian diatas penelitian ini mencoba mengungkap tingkat volatilitas harga saham individual dan IHSG untuk melihat risiko relative saham perbankan melalui metode rata-rata bergerak dalam memprediksi harga saham yang akan dipergunakan untuk penentuan return yang digunakan dalam formulasi estimasi beta, sehingga pengambilan keputusan investasi di bursa saham dapat dilakukan dengan cepat dan aman.

Emiten perbankan dijadikan objek penelitian penulis, karena adanya wacana bahwa harga saham perbankan di awal tahun 2011 akan melemah tetapi ada pula yang menyatakan bahwa saham perbankan akan menguat, hal ini tentu akan membuat keraguan dalam berinvestasi di saham perbankan, seperti yang diuraikan di bawah ini oleh Asteria $(2011 ; 1)$ sebagai berikut:

Pengamat pasar modal Irwan Ariston Napitupulu (2011) mengatakan saham perbankan saat ini masih tertekan akibat memburuknya indeks saham gabungan, menyusul kekhawatiran tingginya inflasi Januari. Ekspektasi pasar bahwa Bank Indonesia (BI) akan menaikkan Giro Wajib Minimun (GWM) untuk meredam inflasi, berimbas buruk bagi sektor perbankan. "Terutama karena naiknya GWM akan menyebabkan dana untuk kredit berkurang dan pertumbuhan pendapatan sektor ini tidak sesuai target".

Pasar menilai Bl akan menaikkan GWM 10-12\% dari posisi saat ini di 8\%, sebagai opsi lain meredam inflasi, selain menaikkan suku bunga acuan. Terutama karena saat ini belum ada urgensi bagi BI untuk menaikkan suku bunga, yang hanya digunakan untuk menahan capital inflow ke Indonesia. Dengan cadangan devisa yang masih tinggi, aliran dana masuk ini belum terancam risiko sudden revearsal (pembalikan arus masuk). Apalagi rupiah stabil di 9000-9100 per dolar AS.
Sementara Viviet S Putri (Anugerah Sekurindo 2011) melihat, bursa masih berpeluang menguat. Koreksi di sesi pertama ini dinilai hanya reaksi sementara, atas matinya sistem informasi Bursa Efek Indonesia 15 menit sebelum penutupan perdagangan tanggal 19 Januari 2011.

Pemerintah dikabarkan akan menjual rights-nya atas hak pada right issue BMRI dengan diskon 8\%, tanpa disebutkan apakah diskon ini dilakukan terhadap cum price atau Theoretical Exrights Price (TERP). Pemerintah memiliki 13,8 miliar lembar saham BMRI, sehingga jumlah saham BMRI yang akan dilepas sebanyak 1,5 miliar lembar saham (rasio 8.9 lama : 1 baru). Book building dilakukan dari 17-21 Januari dengan pricing saham pemerintah dan right issue pada 24 Januari.

\section{Kerangka Pemikiran}

Kerangka berfikir dari penelitian ini dimulai dari penggunaan analisis metode peramalan Exponential Moving average (XMA) dalam menentukan volatilitas harga saham, dimana output berupa data harga yang dihasilkan digunakan untuk memprediksi atau mengestimasi suatu risiko relatif dari return saham individual terhadap return pasar yang di-proxy oleh IHSG melalui estimasi beta.

Dari hal tersebut diharapkan dapat terlihat bahwa arah pergerakan saham atau volatilitas saham dalam suatu periode pengamatan dapat dianalisis, begitu pula dengan tingkat risiko saham, sehingga bisa menipis anggapan bahwa arah pergerakan saham serta tingkat risikonya tidak dapat diketahui, karena output dari analisis volatilitas saham dengan metode rata-rata bergerak Exponential Moving average (XMA) dan estimasi beta dapat digunakan investor ataupun praktisi di pasar modal untuk mengetahui tingkat volatilitas beserta tingkat risiko relatif yang aman bagi investasi. Kerangka pemikiran tersebut dapat terlihat seperti Gambar 2 berikut: 


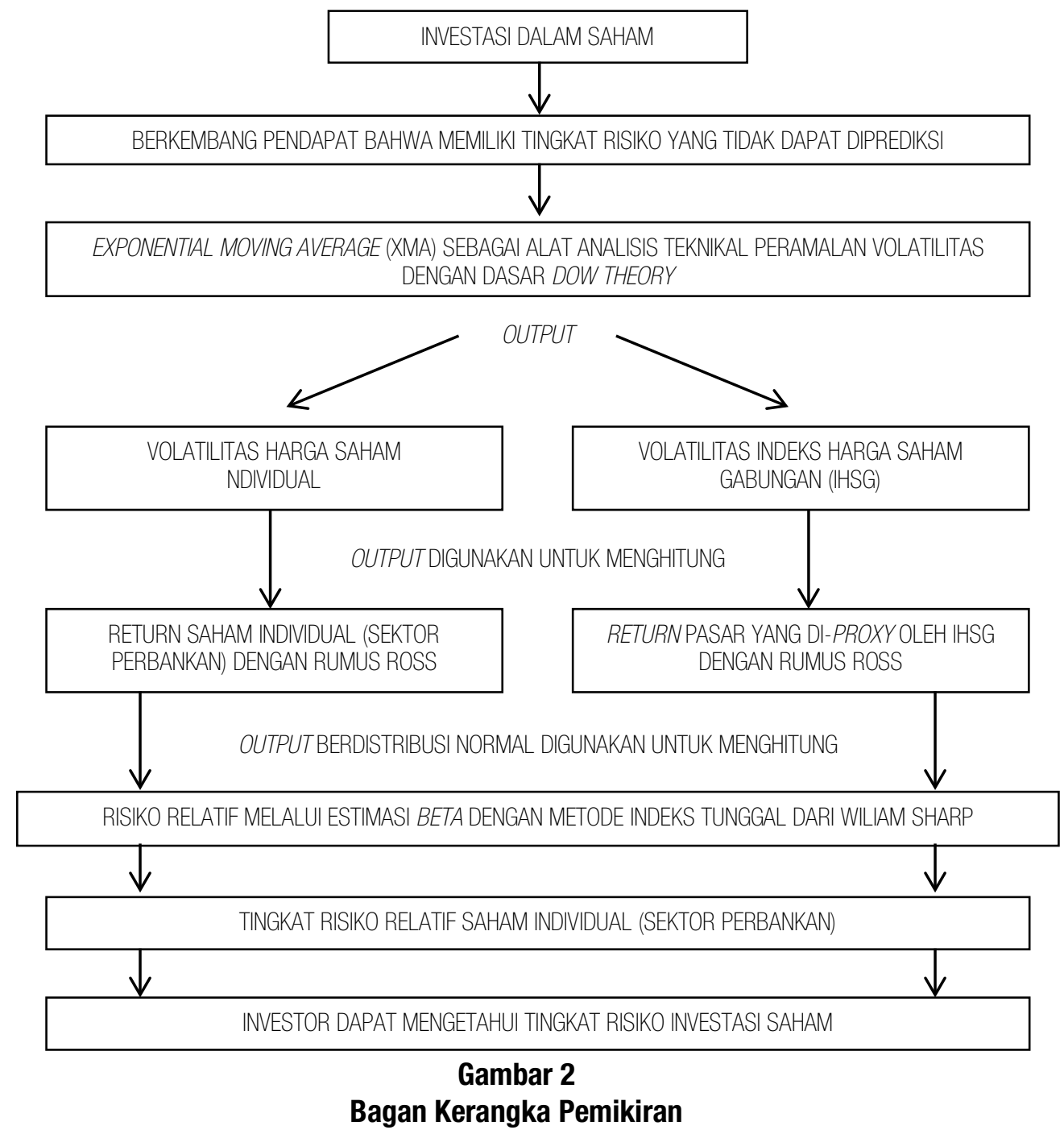

\section{$2.1 \quad$ Hipotesis penelitian}

Berdasarkan kerangka pemikiran di atas dapat dirumuskan hipotesis sebagai berikut :

1. Melalui estimasi beta dan metode Exponential Moving Average dapat dihitung tingkat risiko saham perbankan di Bursa Efek Indonesia.

2. Conditional volatility dapat menjelaskan seluruh perbedaan cross-sectional di dalam pengembalian return saham melalui risiko differential saham perbankan di Bursa Efek Indonesia.

\section{Metode Penelitian}

Penelitian yang dilakukan ini bertujuan untuk mendeskripsikan tentang teknik perhitungan risiko saham melalui output analisis volatilitas indeks harga saham gabungan dan individual, kepada investor yang melakukan investasi saham di bursa saham dan juga bertujuan mengetahui conditional volatility untuk menjelaskan seluruh perbedaan cross-sectional di dalam pengembalian return saham melalui risiko differential saham.

Dari penjelasan tersebut diatas maka metode penelitian yang digunakan dalam penelitian ini adalah studi deskriptif yang bertujuan untuk mengetahui dan menjadi mampu untuk menjelaskan karakteristik variable yang diteliti dalam suatu situasi (Uma Sekaran 2006;158).

\section{Tabel 2}

\section{Operasionalisasi Variabel}

\begin{tabular}{|c|c|c|}
\hline $\begin{array}{c}\text { Variabel/sub } \\
\text { variabel }\end{array}$ & Indikator & Skala \\
\hline $\begin{array}{l}\text { Volatilitas Indeks } \\
\text { Harga Saham } \\
\text { Gabungan } \\
\text { (HSG) }\end{array}$ & Harga akhir periode peramalan & Rasio \\
\hline
\end{tabular}




\begin{tabular}{|l|c|c|}
\hline \multicolumn{1}{|c|}{$\begin{array}{c}\text { Variabel/sub } \\
\text { variabel }\end{array}$} & Indikator & Skala \\
\hline $\begin{array}{l}\text { Volatilitas Harga } \\
\text { saham emiten } \\
\text { perbankan }\end{array}$ & Harga akhir periode peramalan & Rasio \\
\hline $\begin{array}{l}\text { Tingkat Risiko } \\
\text { saham } \\
\text { perbankan di BEl }\end{array}$ & $\begin{array}{c}\text { Tingkat perbandingan return individual } \\
\text { saham dengan return pasar keseluruhan } \\
\text { (gabungan) yang menghasilkan tingkat } \\
\text { risiko relatif saham }\end{array}$ & Rasio \\
\hline
\end{tabular}

Tabel 3

Daftar Emiten Perbankan Di Bursa Saham Indonesia

\begin{tabular}{|c|c|c|}
\hline $\begin{array}{l}\text { Kode } \\
\text { Emiten }\end{array}$ & Emiten & Tanggal IPO \\
\hline AGRO & Bank Agroniaga Tbk & 08 Aug 2003 \\
\hline INPC & Bank Artha Graha Internasional Tbk & 29 Aug 1990 \\
\hline BBKP & Bank Bukopin Tbk & 10 Juli 2006 \\
\hline BNBA & Bank Bumi Arta Tbk & 31 Dec 2099 \\
\hline BACA & Bank Capital Indonesia Tbk & 04 Oct 2007 \\
\hline BBCA & Bank Central Asia Tbk & 31 May 2000 \\
\hline BCIC & Bank Century Tbk & 25 Juni 1997 \\
\hline BNGA & Bank CIMB Niaga Tbk & 29 Nov 1989 \\
\hline BDMN & Bank Danamon Indonesia Tbk & 06 Dec 1989 \\
\hline BAEK & Bank Ekonomi Raharja Tbk & 08 Jan 2008 \\
\hline SDRA & Bank Himpunan Saudara 1906 Tbk & 15 Dec 2006 \\
\hline BABP & Bank ICB Bumiputera Tbk & 15 Juli 2002 \\
\hline BNII & Bank Internasional Indonesia Tbk & 21 Nov 1989 \\
\hline BKSW & Bank Kesawan Tbk & 21 Nov 2002 \\
\hline BMRI & Bank Mandiri (Persero) Tbk & 14 Juli 2003 \\
\hline MAYA & Bank Mayapada Internasional Tbk & 29 Aug 1997 \\
\hline MEGA & Bank Mega Tbk & 17 April 2000 \\
\hline BBNI & Bank Negara Indonesia Tbk & 25 Nov 1996 \\
\hline BBNP & Bank Nusantara Parahyangan Tbk & 10 Jan 2001 \\
\hline NISP & Bank OCBC NISP Tbk. & 20 Oct 1994 \\
\hline PNBN & Bank Pan Indonesia Tbk. & 29 Dec 1982 \\
\hline BNLI & Bank Permata Tbk & 15 Jan 1990 \\
\hline BEKS & Bank Pundi Indonesia Tbk & 13 Juli 2001 \\
\hline BBRI & Bank Rakyat Indonesia (Persero) Tbk & 10 Nov 2003 \\
\hline BSWD & Bank Swadesi Tbk & 01 May 2002 \\
\hline BVIC & Bank Victoria International Tbk & 30 Juni 1999 \\
\hline MCOR & Bank Windu Kentjana International Tbk & 03 Juli 2007 \\
\hline
\end{tabular}

Sumber: PT. Bursa Efek Indonesia

Observasi dilakukan pada 27 bank dari total 34 bank yang terdaftar sebagai emiten di Bursa Efek Indonesia. Analisis Tingkat Volatilitas Harga Dengan Metode Peramalan XMA (Exponential Moving average), Uji Normalitas Data Metode yang digunakan dalam penelitian ini adalah metode penelitian kuantitatif, melalui analisis statistik parametris, karena menganalisis data interval yang diambil dari populasi yang berdistribusi normal (Sugiyono
2006). Pengukuran tingkat kesalahan estimasi beta dengan output exponential moving average (XMA) menggunakan mean absolute percent error (MAPE).

\section{Hasil Pengufian}

\subsection{Analisis Risiko Relatif Saham Melalui Estimasi Beta}

\section{Uji Normalitas Data}

\begin{tabular}{|l|r|r|r|r|r|r|}
\hline \multicolumn{7}{|c|}{ Tests of Normality } \\
\hline & \multicolumn{1}{|c|}{ Kolmogorov-Smirnov } & \multicolumn{3}{|c|}{ Shapiro-Wilk } \\
\hline & Statistic & df & Sig. & Statistic & df & Sig. \\
\hline ARGO & .348 & 34 & .000 & .671 & 34 & .000 \\
\hline INPC & .198 & 34 & .002 & .795 & 34 & .000 \\
\hline BBKP & .154 & 34 & .041 & .915 & 34 & .012 \\
\hline BNBA & .106 & 34 & $.200^{*}$ & .970 & 34 & .460 \\
\hline BACA & .176 & 34 & .009 & .887 & 34 & .002 \\
\hline BBCA & .092 & 34 & .200 & .980 & 34 & .764 \\
\hline BCIC & .408 & 34 & .000 & .564 & 34 & .000 \\
\hline BNGA & .151 & 34 & .047 & .953 & 34 & .154 \\
\hline BDMN & .098 & 34 & .200 & .970 & 34 & .474 \\
\hline BAEK & .159 & 34 & .029 & .928 & 34 & .027 \\
\hline SDRA & .219 & 34 & .000 & .652 & 34 & .000 \\
\hline BABP & .169 & 34 & .015 & .881 & 34 & .001 \\
\hline BNII & .219 & 34 & .000 & .835 & 34 & .000 \\
\hline BKSW & .341 & 34 & .000 & .651 & 34 & .000 \\
\hline BMRI & .129 & 34 & .162 & .938 & 34 & .054 \\
\hline MAYA & .310 & 34 & .000 & .703 & 34 & .000 \\
\hline MEGA & .134 & 34 & .129 & .930 & 34 & .032 \\
\hline BBNI & .112 & 34 & .200 & .926 & 34 & .024 \\
\hline BBNP & .441 & 34 & .000 & .459 & 34 & .000 \\
\hline NISP & .267 & 34 & .000 & .693 & 34 & .000 \\
\hline PNBN & .091 & 34 & .200 & .982 & 34 & .839 \\
\hline BNLI & .212 & 34 & .000 & .918 & 34 & .014 \\
\hline BEKS & .239 & 34 & .000 & .849 & 34 & .000 \\
\hline BBRI & .140 & 34 & .088 & .947 & 34 & .101 \\
\hline BSWD & .481 & 34 & .000 & .212 & 34 & .000 \\
\hline BVIC & .182 & 34 & .006 & .859 & 34 & .000 \\
\hline MCOR & .193 & 34 & .002 & .918 & 34 & .014 \\
\hline & & & & & & \\
\hline
\end{tabular}

Dari tabel Uji Normalitas Data dapat diketahui, dari 27 saham perbankan yang memenuhi kreteria nilai signifikan pada uji Kolmogorov-Smirnov lebih yang besar 
dari tingkatan alpha yang ditentukan yaitu sebesar 0,05 adalah saham BNBA, BBCA, BDMN, BMRI, MEGA, BBNI, PNBN dan saham BBRI. Dan data yang telah diuji dapat digunakan lebih lanjut pada penelitian ini.

\subsection{Estimasi Beta}

Estimasi beta digunakan untuk mengetahui berapa besar risiko relatif yang dimiliki suatu saham dilihat dari tingkat volatilitas return. Menurut Jogiyanto Hartono (2009) beta merupakan suatu pengukur volatilitas (volatility) return suatu sekuritas atau return portofolio terhadap return pasar. Beta sekuritas ke-i mengukur volatilitas return sekuritas ke-i dengan return pasar. Beta portofolio mengukur volatilitas return portofolio dengan return pasar. Dengan demikian beta merupakan pengukur risiko sistimatik (systematic risk) dari suatu sekuritas atau portofolio relatif terhadap risiko pasar.

Estimasi beta yang dilakukan menggunakan metode indeks tunggal dari William Sharp dengan formulasi sebagai berikut:

$$
Y=\beta_{0}+\beta_{1} X+\varepsilon
$$

dimana $Y=$ return individual, $\boldsymbol{\beta}_{0}=$ bagian return sekuritas individual yang tidak dipengaruhi kinerja pasar, $\beta_{1}=$ ukuran kepekaan return sekuritas individual terhadap perubahan return pasar, $X=$ Return indeks harga saham gabungan (return indeks pasar) dan $\varepsilon=$ kesalahan residual. Berdasarkan formula tersebut dapat dihitung:

$$
\begin{aligned}
& \bar{X}=\frac{\sum X}{n} \\
& \bar{Y}=\frac{\sum Y}{n} \\
& \beta_{1}=\frac{\sum X Y-n \overline{X Y}}{\sum X^{2}-\mathbf{n} \bar{X}^{2}} \\
& \beta_{0}=\bar{Y}-\beta_{1} \bar{X}
\end{aligned}
$$

Perhitungan estimasi beta tersebut dilaksanakan dengan bantuan perangkat software Excel Slope yang memiliki tingkat akurasi yang baik untuk jumlah data yang besar. Hasil dari perhitungan estimasi beta pada 8 (delapan) saham perbankan yang memenuhi kreteria uji normalitas, terhadap return pasar yang diproxy oleh IHSG dapat dilihat pada table berikut :

\section{Tabel 5}

Hasil Analisis Estimasi Beta

\begin{tabular}{|c|l|r|}
\hline $\begin{array}{c}\text { Kode } \\
\text { Saham }\end{array}$ & \multicolumn{1}{|c|}{ Nama Bank } & \multicolumn{1}{c|}{ Nilai Beta } \\
\hline BNBA & Bank Bumi Arta Tbk & 1,385302483 \\
\hline BBCA & Bank Central Asia Tbk & 0,583949331 \\
\hline BDMN & Bank Danamon Indonesia Tbk & 1,28123699 \\
\hline BMRI & Bank Mandiri (Persero) Tbk & 1,290860575 \\
\hline MEGA & Bank Mega Tbk & $-0,131361919$ \\
\hline BBNI & Bank Negara Indonesia Tbk & 1,669844302 \\
\hline PNBN & Bank Pan Indonesia Tbk & 0,884268633 \\
\hline BBRI & Bank Rakyat Indonesia (Persero) Tbk & 0,834865216 \\
\hline
\end{tabular}

\subsection{Pengukuran tingkat kesalahan Estimasi Beta Dengan Output XMA Menggunakan MAPE}

Untuk memastikan bahwa tingkat kesalahan dari estimasi beta yang mempergunakan output dari analisis volatilitas exponential moving average (XMA) tidak terlalu besar dan memenuhi tingkat kepercayaan dalam penelitian, maka dipergunakan model pengukuran tingkat kesalahan mean absolute percent error (MAPE), yang menghitung rata-rata diferensiasi absolut antara nilai yang diramal dan aktual.

Tingkat kesalahan perhitungan estimasi beta dengan mempergunakan output dari analisis volatilitas exponential moving average (XMA), yang diukur melalui mean absolute percent error (MAPE) menunjukan tingkat kesalahan 5,73\%, yang berarti bahwa akurasi perhitungan dari analisis tersebut mencapai 94,27\%. Hal tersebut dapat dilihat pada Table 6 di bawah ini :

\section{Tabel 6}

Hasil Perhitungan Mean Absolute Percent Error (MAPE) Dalam Estimasi Beta

\begin{tabular}{|c|l|l|c|c|c|c|}
\hline No & $\begin{array}{c}\text { Kode } \\
\text { Saham }\end{array}$ & \multicolumn{1}{|c|}{ Nama Bank } & $\begin{array}{c}\text { Nilai } \\
\text { Beta }\end{array}$ & $\begin{array}{c}\text { Nilai Beta } \\
\text { Riil }\end{array}$ & $\begin{array}{c}\text { Selisih } \\
\text { kesalahan }\end{array}$ & $\begin{array}{c}\text { Kesalahan Persen } \\
\text { Absolut 100 } \\
\text { (Kesalahan/Aktual) }\end{array}$ \\
\hline 1 & BNBA & Bank Bumi Arta Tbk & 1,39 & 1,35 & 0,03 & 2,35 \\
\hline 2 & BBCA & Bank Central Asia Tbk & 0,58 & 0,64 & 0,05 & 8,15 \\
\hline 3 & BDMN & Bank Danamon Indonesia Tbk & 1,28 & 1,25 & 0,03 & 2,76 \\
\hline 4 & BMRI & Bank Mandiri (Persero) Tbk & 1,29 & 1,34 & 0,05 & 3,96 \\
\hline
\end{tabular}




\begin{tabular}{|c|l|l|c|c|c|c|}
\hline No & $\begin{array}{c}\text { Kode } \\
\text { Saham }\end{array}$ & \multicolumn{1}{|c|}{ Nama Bank } & $\begin{array}{c}\text { Nilai } \\
\text { Beta }\end{array}$ & $\begin{array}{c}\text { Nilai Beta } \\
\text { Riil }\end{array}$ & $\begin{array}{c}\text { Selisih } \\
\text { kesalahan }\end{array}$ & $\begin{array}{c}\text { Kesalahan Persen } \\
\text { Absolut 100 } \\
\text { (Kesalahan/Aktual) }\end{array}$ \\
\hline 5 & MEGA & Bank Mega Tbk & $-0,13$ & $-0,15$ & $-0,02$ & 14,29 \\
\hline 6 & BBNI & Bank Negara Indonesia Tbk & 1,67 & 1,64 & 0,03 & 1,74 \\
\hline 7 & PNBN & Bank Pan Indonesia Tbk & 0,88 & 0,90 & 0,02 & 2,01 \\
\hline 8 & BBRl & Bank Rakyat Indonesia (Persero) Tbk & 0,83 & 0,75 & 0,08 & 10,62 \\
\hline \multicolumn{2}{|l}{} & Jumlah & $\%$ kesalahan & 45,88 \\
\cline { 5 - 6 } & MAPE & $\%$ & 5,73 \\
\hline
\end{tabular}

\section{Pembahasan Hasil Penelitian}

\subsection{Pembahasan Analisis Volatilitas Saham}

Dari gambar grafik hasil analisis aplikasi metode Exponential Moving average (XMA) 2 periode pada volatilitas 27 saham perbankan di Bursa Efek Jakarta tidak semua saham perbankan mengalami penurunan ataupun kenaikan harga di akhir periode penelitian, yaitu pada bulan Desember 2010, yang dapat menunjukan pola pergerakan di awal tahun 2011. 16 (enam belas) Saham mengalami penguatan, 9 (Sembilan) saham mengalami penurunan dan 2 saham tidak bergerak (flat)

\subsection{Pembahasan Analisis Estimasi Beta}

Hasil dari langkah-langkah pengestimasian Beta, terdapat 8 saham perbankan yang memiliki tingkat pergerakan return yang normal dan tidak memperlihatkan adanya Outlier atau data ekstrem yang dapat membuat estimasi menjadi bias, atau menunjukan pergerakan volatilitas return saham yang ekstrem. Yang menarik dari hasil analisis estimasi beta, terlihat bahwa saham BBRI walaupun memiliki trend primer yang melemah diakhir periode tetapi memiliki tingkat pergerakan return yang menguntungkan investor selama periode pengamatan.

Dari Tabel 5 terlihat beta dari BBNI menunjukan bahwa saham tersebut memiliki kepekaan return individual terhadap return pasar yang paling tinggi dibandingkan dengan 8 (delapan) saham yang lain yaitu sebesar 1,669844302, hal ini berarti setiap perubahan volatilitas return pasar akan sangat berpengaruh besar terhadap perubahan volatilitas return saham BBNI. Jika IHSG menguat maka saham BBNI pun akan mengikuti trend yang terjadi pada volatilitas IHSG sebagai proxy return pasar. Demikian pula sebaliknya jika IHSG mengalami penurunan atau keterpurukan maka saham inipun akan mengalami hal yang sama.
Saham MEGA dari Tabel 5 mengenai analisis estimasi beta memiliki beta yang terkecil dibandingkan dengan 8 saham yang lain sebesar -0,131361919. Hal ini menunjukan bahwa saham MEGA memiliki kepekaan return individual terhadap return IHSG sebagai proxy return pasar yang terkecil pula. Setiap perubahan terhadap volatilitas return IHSG tidak selalu dilkuti oleh perubahan volatilitas return pada saham MEGA. Jika IHSG memiliki trend naik, return saham MEGA tidak selalu mengikuti trend tersebut, begitu pula jika IHSG mengalami penurunan atau keterpurukan, saham inipun tidak selalu mengikuti trend tersebut.

beberapa implikasi hasil penelitian ini yang dapat dikemukakan. Pertama, Anggapan bahwa pergerakan harga saham pada saat ini tidak dapat diprediksi atau diramalkan (Totally Random) dan hanya mengikuti pergerakan trend dan menyebabkan aksi panic selling tidak sepenuhnya benar. melalui metode penelitian ini aksi panic selling diharapkan akan dapat dihindari.

Kedua, hasil penelitian ini menunjukan bahwa dalam bertransaksi di bursa saham pelaku pasar tidak hanya menggunakan metode rata-rata bergerak Exponential Moving average (XMA) untuk melihat timing yang tepat untuk bertransaksi tetapi harus melihat normalitas data volatilitas return sebagai suatu langkah pengestimasian beta sebagai pengukur volatilitas (volatility) return suatu sekuritas atau return portofolio terhadap return pasar, sehingga tingkat risiko relatif saham dalam suatu portofolio dapat diketahui, karena akan berimplikasi kepada tingkat keakuratan dan keamanan dalam berinvestasi atau menentukan portofolio saham.

Ketiga, kondisi pasar modal kita yang termasuk pasar bentuk lemah (Weak Market) seperti yang diungkapkan pada penelitian Anton (2006;2) sehingga data historis tidak dapat digunakan untuk mengambil keputusan investasi. Dalam penelitian ini dapat diketahui sesungguhnya data historis yang berbentuk time series 
tersebut masih dapat dipergunakan untuk mengambil keputusan investasi dengan melihat korelasi antara pergerakan volatilitas saham individual terhadap pergerakan volatilitas harga pasar dalam menghasilkan retun dalam proses estimasi beta, sehingga jelas terlihat bobot risiko sistematis dari masing-masing saham dalam periode masala lalu maupun di masa yang akan datang.

Keempat, hasil penelitian tersebut dapat dipergunakan investor ataupun praktisi pasar modal sebagai alat mengambil keputusan investasi dan bermanfaat bagi akademisi untuk melakukan penelitian lebih lanjut dalam meneliti masalah risiko serta volatilitas saham sebagai penyempurnaan keterbatasan penelitian yang telah dilakukan.

\section{Kesimpulan}

1. Tingkat risiko saham perbankan di Bursa Efek Indonesia dapat dihitung melalui estimasi beta dan metode Exponential Moving Average, yang ditunjukan melalui besarnya nilai beta masing-masing saham, dengan kreteria semakin tinggi nilai beta semakin tinggi tingkat risiko saham. Dengan hasil uji bias sebesar 0,97 dan tingkat kesalahan 5,73\%, mempunyai arti bahwa kedua metode tersebut dapat digunakan untuk memprediksi tingkat risiko saham dalam berinvestasi di Bursa Efek Indonesia

2. Conditional volatility dapat menjelaskan seluruh perbedaan cross-sectional di dalam pengembalian return saham melalui risiko differential saham perbankan di Bursa Efek Indonesia, dilihat dari perbandingan besarnya deviasi pergerakan harga yang menghasilkan return saham yang dipergunakan untuk perhitungan risiko saham, ini berarti bahwa analisis volatilitas saham dalam estimasi beta pada periode waktu tertentu (conditional volatility) dapat dipergunakan untuk melihat seberapa besar pengembalian return dari tingkat risiko masing-masing saham.

\section{Rekomendasi}

1. Sebagai bahan penelitian selanjutnya, hasil uji bias yang menunjukan nilai 0,97 dan pengukuran tingkat kesalahan estimasi beta dengan output exponential moving average (XMA) menggunakan mean absolute percent error (MAPE) dengan nilai kesalahan 5,73\% dapat disempurnakan oleh metode-metode lainnya yang berhubungan dengan analisis volatilitas dan estimasi beta.

3. Objek dan sampel penelitian diharapkan dapat lebih diperluas tidak hanya di Bursa Efek Indonesia khususnya disektor perbankan, di objek penelitian lainnya dengan sektor-sektor yang lebih bervariasi.

4. Perhitungan untuk optimalisasi portofolio risiko dalam berinvestasi di bursa saham diharapkan tidak hanya dilakukan melalui satu metode optimalisasi saja tetapi harus didukung oleh hasil metode yang lainnya, sehingga hasil optimalisasi portofolio risiko dalam berinvestasi, sesuai dengan apa yang diharapkan.

\section{Daftar Pustaka}

Anton, 2006, Analisis Model Volatilitas Return Saham, Semarang, Universitas Diponegoro.

Adler, H. Manurung, 2008, Ke Arah Mana Siklus Bursa Bergerak, Jakarta, Jurnal Penelitian Pergerakan IHSG di BEl.

Adler, H. Manurung, 2007. Estimasi Harga Haircuts Saham di BEJ, Studi Kasus Saham, Jakarta, Kertas Kerja PT. Nikko Securities Indonesia dan Pascasarjana \& MM-FEUl.

Asteria, 2011. Saham Bank Akan Rebound, Inilah.com (Online), 3 halaman, Tersedia; www.pasarmodal.inilah.com, (20 Januari 2011)

Hartono, Jogiyanto, 2009. Teori Portofolio dan Analisis Investasi, Yogyakarta, BPFE.

Kumianny A.Saputra, Elly. 1999. Pengaruh Risiko Sistematis dan Likuiditas Terhadap Tingkat Pengembalian Saham Badan-Badan Usaha yang Go-Public di Bursa Efek Jakarta pada Tahun 1999. Jurnal Manajemen dan Kewirausahaan: Maret 2002 Vol. 4, No. 1. Universitas Kristen Petra, Surabaya. 
Osak, Ronald, 2000. Peramalan Volatilitas Rupiah Sebagai Upaya Optimalisasi Portofolio Valas, Semarang, Universitas Diponegoro.

Ramantha, I Wayan, 2006. Pengaruh Volume Perdagangan dan Volatilitas Harga Saham Terhadap Bid-ask Spread pada Saham Teraktif di Bursa Efek Jakarta, Denpasar, Universitas Udayana.

Syamsir, Hendra, 2004. Solusi Investasi di Bursa Saham Indonesia, Jakarta, Elex Media Komputindo.

Suharli, Michell, 2005. Studi Empiris Terhadap Dua Faktor Yang Mempengaruhi Return Saham Pada Industri Food \& Beverage Di Bursa Efek Jakarta, Surabaya, Universitas Kristen Petra.

Sekaran, Uma, 2006, Research Methods For Business, Jakarta, Salemba Empat.

Sugiyono. 2006. Metode Penelitian Bisnis. Bandung: Alfabeta. 